\title{
関東ロームのアロフェン含有量がその土質工学的特異挙動に及ぼす影響 $\left.\begin{array}{l}\text { Influence of Allophane Contents on the Abnormal } \\ \text { Engineering Behaviour of Volcanic Cohesive Soils }\end{array}\right)$
}

\author{
宋永焜 $\mathrm{i}$ (Ei-Kon So)
}

キーワーズ : アロフェン含有量 /液性限界 / 鋭敏比 /オーバー コクパクション/関東ローム/強度回復/締固め/透水性 $/ \mathrm{pF}$ 曲線/分散 $(\mathbf{I G C : D 2 / D} 9 / \mathrm{D} 6)$

\section{1. 序}

\section{論}

関東ロームは本邦の特殊土の一つであり, 関東地方に広く分布す る火山灰質粘性土である。この土は洪積世時代 (200万年〜 1 万年 前）に富士，箱根火山群や愛鷹山などが噴火して推積された火山灰 の風化土である。このような火山灰土は世界的にみても八ワイ，二 ユージランド，およびインドネシアにしか存在しない特殊土であ る。地質学的には地表面加下方に向かって立川ローム, 武蔵野口 一ム (以上を新規ロームという), 下末石ローム, 多摩ローム（古 期ローム）の順に層序をもって推積し, 立川ロームが最も新しく, 以下順に古くなる1),6)。

これらの層には，おのおの違った微細結晶である粘土鉱物を有し ている。立川ロームは, ほぼ地表面下 $5 \mathrm{~m}$ 以上に推積し, 主とし て多量のアロフェン粘土鉱物を含有している。このため立川ローム は土質工学的に最も問題の多い土であり, 人間生活に密着したロー ム層である。武蔵野ローム層以下からは, 順次アロフェン量が減少 し，代わりに加水ハロイサイト，抢よびハロイサイトなどの粘土鉱 物が多くなる。このように深さにつれて変化する粘土鉱物の分布を 表-1 に示す 1 , 2)。アロフェン粘土鉱物は非晶質で直径約 $50 \AA$ の球 状粘土鉱物了)である。その内部には多量の非自由水分（拘束水分） を有している4)。従来からこのアロフェン粘土鉱物の影響を定性的 に暗示するような研究は少なくない。すなわち，立川ロームの乾燥 密度は他のロームに比べて低く5), 加水ハロイサイトを多く含む

表-1 関東口ームの粘土鉱物分布

\begin{tabular}{l|l|l}
\hline \multicolumn{2}{l|}{} & \multicolumn{1}{c}{ 主な粘土鉱物 } \\
\hline \multicolumn{2}{c|}{ 立川ローム } & アロフェン \\
\hline \multirow{2}{*}{ 武藏野ローム } & $\begin{array}{l}\text { 上部 } \\
\text { 下部 }\end{array}$ & $\begin{array}{l}\text { アロフェンと低結晶の加水ハロイサイト } \\
\text { 加水ハロイサイト }\end{array}$ \\
\hline 下末石ローム & 陸成 & $\begin{array}{l}\text { 加水ハロイサイト } \\
\text { ハロイサイト鉱物の混合型 }\end{array}$ \\
\hline \multirow{2}{*}{ 多 摩ローム } & 海成 & 陸成 \\
& 海成 & $\begin{array}{l}\text { 結晶度の高い加水ハロイサイト } \\
\text { ハロイサイト鉱物の混合型 }\end{array}$ \\
\hline
\end{tabular}

i) 関東学院大学工学部土木工学科 教授（横浜市金沢区六浦町4834） (1993.4.21 原稿受付・討議期限 1995.1.1 要請があれば 1 か月の 期限延長可能)
(アロフェン量が少ない) ものは鋭敏である ${ }^{32)}$ 。なた新しいローム ほど攪乱土の強度は小さく，強度回復は大きい(7),8),9),17)などは，そ の一例である。よって, 従来の説により, アロフェン粘土鉱物に㷌 因すると思われる土質工学的特異挙動を列挙すると次のようにな る。

（1）高い自然含水比と液性限界を有している2。

（2）液性限界などは空気乾燥やねり返しによって減少す $ろ^{4), 10), 11), 12)}$ 。

(3) $\mathrm{pF}$ 曲線は空気乾燥によって変化する4)。

（4）粒度分析では塩酸による酸性分散のほうが有効であ $3^{13), 14)}$ 。

（5）締固め曲線は初期含水此によってその位置を異にし，乾 燥法, 湿潤法の試料処理によって非可逆性を有している16),19)。

（6）顕著なオーバコンパクションおよび強度回復現象（シキ ソトロピー現象）を有する15),17),18)。

（7）鋭敏比が大きく，攪乱土の強度は著しく低下する ${ }^{9), 32) 。 ~}$

（8）乱さない土の透水係数は乱した土より大きく, 透水異方 性を有する。また透水係数は間隙比に依存しない2)。

（9）アロフェン質関東ローム（立川ローム）は石灰，あるい は石灰一石膏混合材とよく反応し，加水ゲーレナイト，エトリンガ イトなどの反応生成物が安定処理に寄与している ${ }^{20)}$ 。ただし多量 の石灰添加量 $(>30 \%)$ が必要である21)。

以上のように地質学的, 土壤学的, 土質工学的に関東ロームに関 する多数の研究が発表されている。しかしアロフェン量の影響に関 する土質工学的な定量的研究は，本邦に括いて，著者らの一連の研 究22),23),24)以外にはほとんどない現状にある。外国ではニュージー

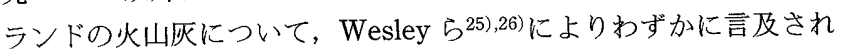
ているのみである。よって本研究は関東ロームのアロフェン含有量 を化学的方法によって ${ }^{30}$ 定量し, 推測の域を出なかった関東ロー ムの土質工学的特異挙動とアロフェン含有量の関係を定量的に求め ようとするものである。このうち(1)に述ベたアロフェン含有量 と自然含水比， あるいは液性限界の関係については，抢のおの直線 関係を有していること（相関係数 $r=0.6 \sim 0.8 ）$ が著者によってす でに報告されている22),23),24)。また，(9）のアロフェン含有量が石

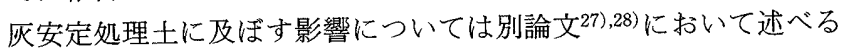
ことにする。

\section{2. 実験試料と実験方法}

(A) 実験試料：関東ロームは主として，南関東ならびに東名高 速改築沿線において採取したものである。乱さない試料は， $\phi 5$ $\mathrm{cm} \times 5 \mathrm{~cm}$ (直径 $\times$ 高さ）と $\phi 5 \mathrm{~cm} \times 2 \mathrm{~cm}$ の円筒を用いて採取し, $q_{u}$ 試験, 透水試験および $\mathrm{pF}$ 試験試料とした。いろいろなアロフェ ン量を有する試料はランダムに採取した後, アロフェン定量試験を 


\begin{tabular}{|c|c|c|c|c|c|c|c|c|c|c|}
\hline 年 & =採取地 & Ap & $\mathrm{w}$ & $\rho_{\mathrm{s}}$ & $w_{L}$ & $w_{P}$ & $I_{P}$ & $\begin{array}{l}d< \\
2 \mu\end{array}$ & $\begin{array}{c}d< \\
74 \mu \\
\end{array}$ & $\begin{array}{c}d< \\
420 \mu \\
\end{array}$ \\
\hline & & $\%$ & $\%$ & $\mathrm{~g} / \mathrm{cm}^{3}$ & $\%$ & $\%$ & $\%$ & $\%$ & $\%$ & $\%$ \\
\hline 4 & 東名 1 & 40.0 & 85.80 & 2.642 & 124.0 & 79.0 & 45.0 & 14.2 & 35.4 & 58.1 \\
\hline 4 & 東名 2 & 39.0 & 55.18 & 2.867 & 86.2 & 60.3 & 25.9 & 0.0 & 25.8 & 50.2 \\
\hline 4 & 東名 3 & 35.0 & 39.0 & 2.808 & 78.8 & 64.0 & 14.8 & 5.9 & 14.3 & 32.4 \\
\hline 4 & 美大 & 75.0 & 106.7 & 2.36 & 123.0 & 99.0 & 24.0 & & & \\
\hline 4 & 能見台 & 22.0 & 36.0 & 2.44 & 49.0 & 35.3 & 13.7 & 6.1 & 66.3 & 95.5 \\
\hline 4 & 上荻野 & 55.0 & 95.9 & 2.36 & 128.0 & 101.6 & 26.4 & 9.2 & 47.6 & 80.5 \\
\hline 4 & 座間 & 20.0 & 105.4 & 2.45 & 104.2 & 71.3 & 32.9 & 7.5 & 46.3 & 77.8 \\
\hline 4 & 沼津 & 66.0 & 181.5 & 2.88 & 177.0 & 76.2 & 100.8 & 2.8 & 10.6 & 37.1 \\
\hline 4 & 東名 1 & 17.0 & 72.4 & 2.95 & 89.4 & 57.6 & 31.8 & 7.8 & 29.5 & 58.0 \\
\hline 4 & 町田 & 32.0 & 96.0 & 3.014 & 107.6 & 52.1 & 55.5 & 10.5 & 46.3 & 77.7 \\
\hline 4 & 多摩 1 & 51.0 & 78.8 & 2.91 & 96.0 & 76.7 & 19.3 & 7.5 & 37.4 & \begin{tabular}{|l|}
69.9 \\
\end{tabular} \\
\hline 4 & 多摩 2 & 20.0 & 93.6 & 2.95 & 83.0 & 63.6 & 19.4 & 5.7 & 55.5 & 91.6 \\
\hline 4 & 多摩 3 & 30.0 & 92.9 & 2.96 & 95.8 & 65.6 & 30.2 & 10.3 & 46.0 & 71.7 \\
\hline 4 & 多摩 4 & 46.0 & 89.6 & 2.93 & 101.0 & 70.8 & 30.2 & 10.8 & 53.1 & 75.0 \\
\hline 3 & 港北 1 & 59.0 & 83.18 & 2.820 & 109.0 & 89.5 & 19.5 & 2.0 & 25.3 & 62.0 \\
\hline 3 & 成瀬 & 38.0 & 105.07 & 2.849 & 113.8 & 95.7 & 18.1 & 9.0 & 39.4 & 71.6 \\
\hline 3 & 秦野 1 & 20.0 & 63.26 & 2.748 & 71.8 & 61.8 & 10.0 & 2.0 & 21.1 & 57.2 \\
\hline 3 & 伊勢原 & 40.2 & 123.44 & 2.750 & 103.0 & 85.8 & 17.2 & 8.0 & 32.3 & 67.0 \\
\hline 3 & 麻溝 1 & 76.0 & 78.8 & 2.811 & 89.2 & 82.6 & 6.6 & 5.0 & 31.9 & 56.8 \\
\hline 3 & 町田 1 & 87.0 & 96.4 & 2.776 & 120.5 & 100.2 & 20.3 & 8.0 & 33.1 & 76.8 \\
\hline 3 & 小田原 1 & 62.0 & 134.8 & 2.860 & 153.7 & 139.2 & 14.6 & 10.0 & 32.0 & 70.0 \\
\hline 3 & 大和 & 52.0 & 78.8 & 2.815 & 91.5 & 71.3 & 20.2 & 2.0 & 26.1 & 50.0 \\
\hline 3 & 厚木 & 18.0 & 59.1 & 2.843 & 66.3 & 62.0 & 4.3 & 6.5 & 37.0 & 62.3 \\
\hline 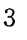 & 麻溝 2 & 40.8 & 100.5 & 2.866 & 103.0 & 85.8 & 17.2 & 7.1 & 35.1 & 73.0 \\
\hline 3 & 町田 2 & 39.8 & 111.8 & 2.865 & 115.8 & 87.2 & 28.6 & 5.8 & 31.2 & 75.0 \\
\hline 3 & 港北 2 & 25.0 & 111.3 & 2.848 & 83.5 & 70.3 & 13.2 & 5.0 & 30.9 & 81.6 \\
\hline 3 & 小田原 2 & 64.0 & 127.3 & 2.863 & 120.5 & 100.2 & 20.3 & 8.0 & 33.6 & 70.3 \\
\hline 3 & 秦野 2 & 16.0 & 64.5 & 2.842 & 66.3 & 62.0 & 4.3 & 6.5 & 19.4 & 41.3 \\
\hline
\end{tabular}

行なって選別した。代表的な関東ロームの物理的性質および粒度分 布などを表-2に示す。

（B）実験方法：（1 ）コンシステンシー限界, 強熱減量, 粒度分 布， $q_{u}$ 試験は大むね土質工学会基準にしたがって行なった。（2） 試料処理法の違いによる締固め試験を土質工学会基準に準じた以外 は，すべてハーバード小型締固め試験機によって行なった。標準締 固めエネルギーは 3 層 $\times 25$ 回 $\times 2.5 \mathrm{~kg}$ （または $40 \#$ ハーバード型タ ンバー）である。な打，強度回復現象試験のための供試体養生は， 含水比保持のためパラフインでシールし，湿潤箱に入れて所定日数 養生した。（3）ねり返しテストは試料をビニール袋に入れ，ガラ ス板上に手でねりながら必要時間だけ行なった。（4）透水試験は $\phi 5 \mathrm{~cm} \times 5 \mathrm{~cm}$ 円筒試料による簡易型変水位透水試験で行なった。（5 ) $\mathrm{pF}$ テストは広域圧力板法（ $\mathrm{pF}=2.0 \sim 4.2$ まで連続測定可能）を用 い、ほぼ土質工学会基準によって行なった。（6）アロフェン含有 量の定量は，現在までまだ一定の基準法はないが，ここでは北川の $8 \mathrm{NHCl}-1 / 2 \mathrm{NNaOH}$, 交互溶解法 ${ }^{30}$ )によって行なった。その手順を 図-1に，代表的な定量曲線を図-2に示した。この原理は次の通り でせる。土の酸およびアルカリに対する溶解速度は結晶性鉱物に比 較して非晶質性鉱物(アロフェン)のほうがはるかに早い。ゆえに， 土を適当な酸またはアルカリ溶液でくり返し処理した場合, 土の非 晶質鉱物成分の溶出含量は当初急激に増加し, それ以後は結晶性鉱 物の溶出を示すゆるやかな直線的增加を示す。この溶解パターンを 示す曲線の直線部分を延長して, $\mathrm{y}$ 軸との交点を求めることにより アロフェン非晶質鉱物の含有量を知ることができる。（7) X 線回 折試料は $420 \mu$ フルイ通過試料をメノウ針中で, 十分細かくなるま ですったものを使用した。X 線回折の実験条件は表-3の通りであ

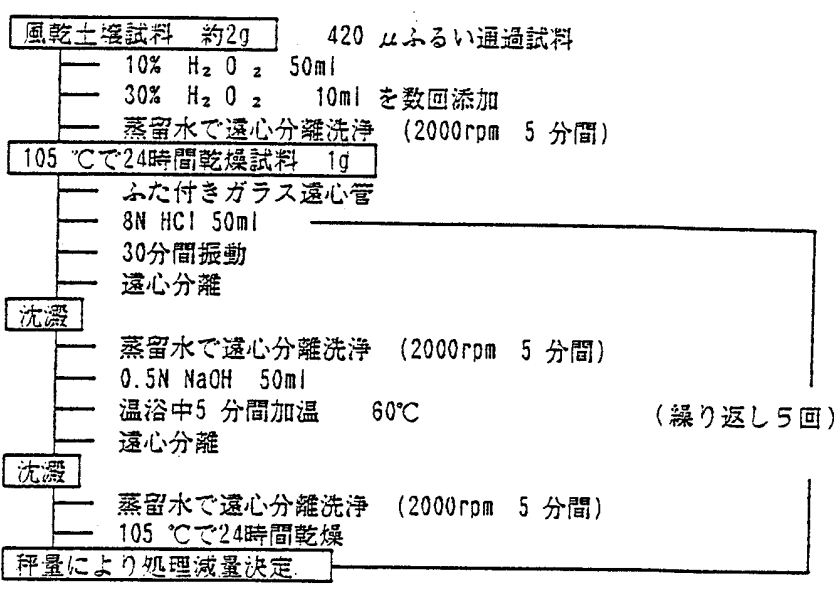

図-1 アロフェン定量フローチャート

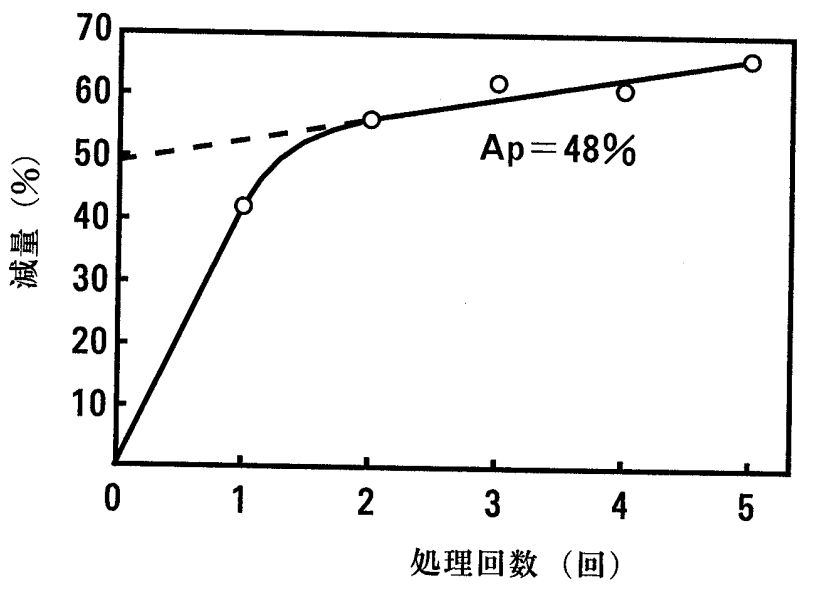

図-2 アロフェン定量法曲線

表-3 X 線回折の実験定数

\begin{tabular}{l|l|l|l}
\hline \multicolumn{1}{c|}{ 試 料 } & 関東ローム & 走查速度 & \multicolumn{1}{|c}{$2^{\circ} \mathrm{min}^{-1}$} \\
\hline 対陰極 & $\mathrm{CuK} \alpha$ & チャート速度 & $2 \mathrm{~cm} \mathrm{~min}^{-1}$ \\
フィルター & $\mathrm{Ni}$ & 発散スリット & $1^{\circ}$ \\
菅電圧 & $30 \mathrm{kV}$ & 受スリット & $0.1 \mathrm{~mm}$ \\
菅電流 & $20 \mathrm{~mA}$ & レンジ & $5000 \mathrm{cps}$ \\
時定数 & $1 \mathrm{~s}$ & & \\
\hline
\end{tabular}

る。

\section{3. 実験結果および考察}

3.1 関東ロームのアロフェン量別による粘土鉱物の分布（図3)

表-1 で示すように関東ロームは立川ロームなどの層序の変化と ともに含有粘土鉱物の種類と量が変化する。地表の立川ロームに は，多量のアロフェン粘土鉱物のみを含有している。それ以下は深 さとともにアロフェン量は減少し，順に加水ハロイサイト，八ロイ サイトと変化し，その分布境界には両者の混在物が存在することが 知られている1)。図-3は深さと無関係に採取した試料であるが，ア ロフェン量別に比較してみると，このような明瞭な傾向が存在する ことがわかる。すなわち, アロフェン含有量 (以後 Ap と表記する) 


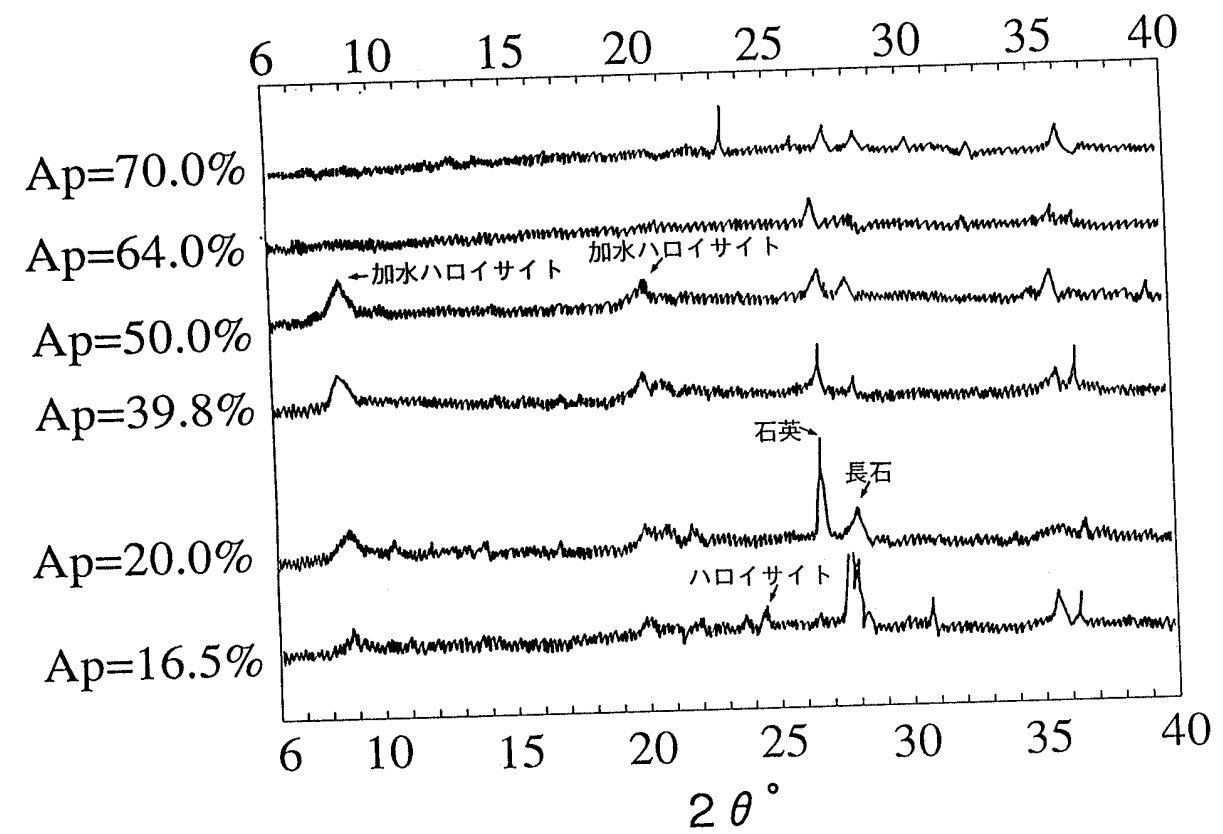

図-3 関東ロームの X 線回折図

$65 \%$ 以上ではアロフェン粘土鉱物しか存在しない。ちなみにアロ フェン粘土鉱物の非晶質ピークは $30^{\circ} \sim 40^{\circ}$ 間の幅広い小ピークで 表されるものといわれている30)。また $\mathrm{Ap}=50 \%$ では加水八ロイサ イトの明瞭なピークしか存在しない。これに対し Ap が $50 \%$ 以下で は, 加水ハロイサイトのピークのほかに不鮮明ながらハロイサイト のピーク $\left(20^{\circ}\right)$ も存在する。一次鉱物である石英, 長石のピーク は，アロフェン量の減少とともに高くなる傾向にあり，従来からい われていることと一致している11,2)。定温, 定圧の深い所では 3 次 元構造の一次鉱物は風化しにくいことを示している。 $\mathrm{Ap}=40 \%$ 50\%層では，アロフェン，加水八ロイサイト，ハロイサイトなど の粘土鉱物が啇当な割合で混在しているものと思われ，時としてア ロフェン量との相関性から大きくはずれた挙動を示すことがあ $ろ^{23), 24)}$ 。

3.2 アロフェン量が空気乾燥, ねり返し, 強熱減量に及ぼす影 響（図-4〜9）

アロフェン含有量は自然含水比, 液性限界などと良好な直線比例 関係を有していることは前に述べてきた。このうちアロフェン量と 乱さない土の空気乾燥含水比の関係を時間を媒介変数として表した のが図-4である。ここでも自然含水比（初日の含水比）はアロフ エン量の増加とともに大きくなる。この自然含水比は, 一般に自由 水と非自由水に分けられ, 後者は前者よりもかなり強い力で構造骨 格の内部に吸着されているといわれている4)。ゆえに自由水の空気 乾燥による消失は早く, 非自由水は緩慢であることが考えられる。 図-4をこのように考えていくと，Ap $<40 \%$ 暏由水の空気乾 燥はほとんど瞬時のうちに消失し，それ以上のアロフェン量では 14日で完了し, 以後は緩慢な非自由水分の空気乾燥による消失で めることがわかる。たたし，Ap=33\%付近の含水比の減少は試料 処理の不備によるものと思われる。14日以後の空気乾燥による消 失量は $\mathrm{Ap}<40 \%$ で約 $20 \%$ ，それ以上の $\mathrm{Ap}$ 量で約 $30 \%$ でありこ れをすべて非自由水分と考えると, 自然含水比の $1 / 3$ から $1 / 4$ にあ たる量である。関東ロームの非自由水分の重要性のほどがわかる。 図一5 は空気乾燥が液性限界に及ぼす影響を示したものである。一 般に試料を自然含水比から段階的に空気乾燥させ, そのたびごとに

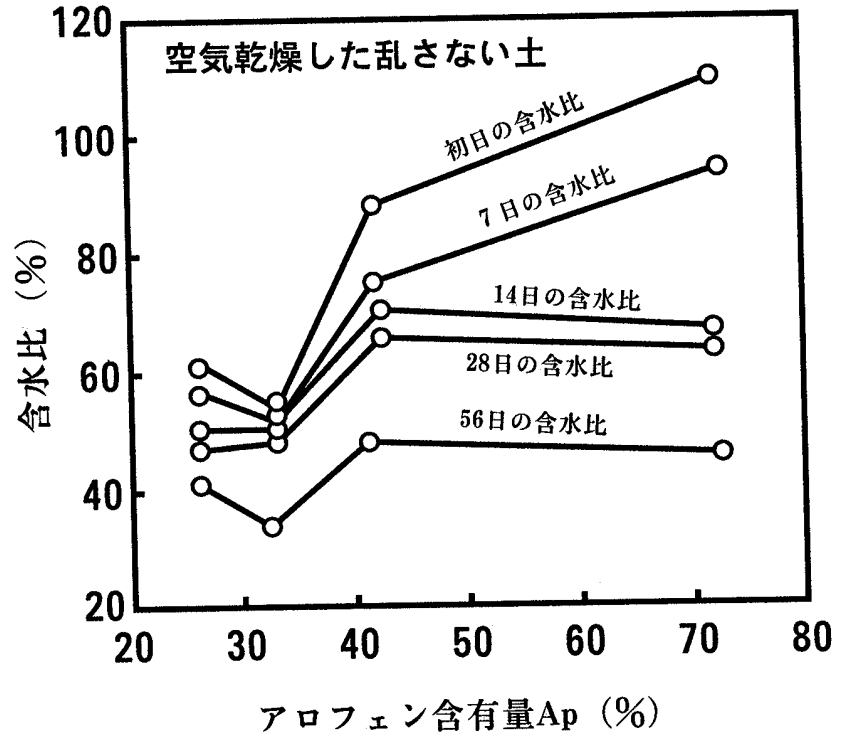

図-4 アロフェン含有量と空気乾燥含水比の関係

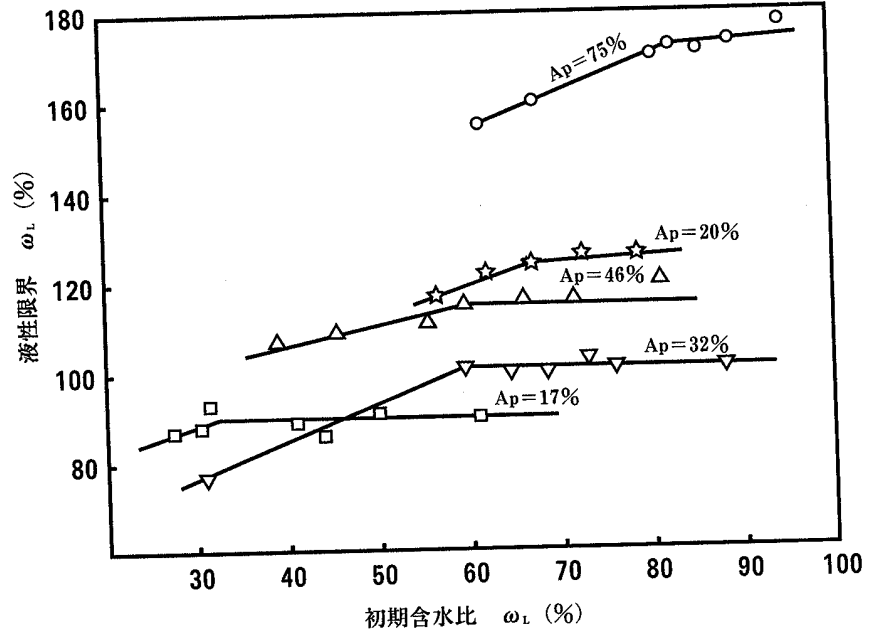

图-5 初期含水比と液性限界の関係 


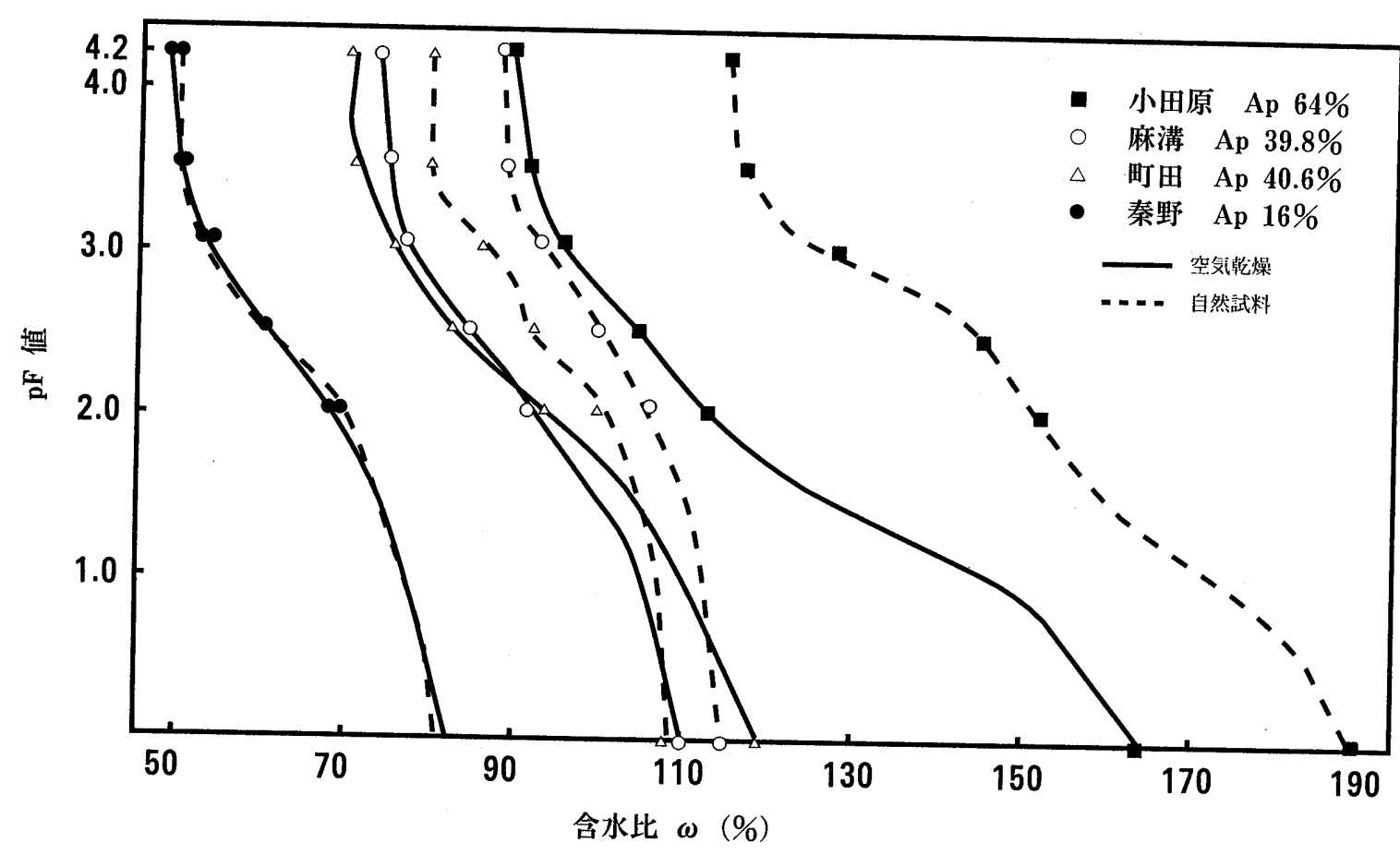

図-6＼cjkstart空気乾燥による $\mathrm{pF}$ 曲線の変化

試験をしてやると, 液性限界はある空気乾燥含水比から低下し始め る。この低下し始めた点に相当する空気乾燥含水比を一般に限界初 期含水比 $\left(w_{i L}\right)$ と呼んでいる10)。な缺塑性限界にもこのような点 が存在するといわれ，この場合には第 2 限界初期含水比 $\left(w_{i p}\right)$ と 名付けられている10)。図-5 はいろいろなアロフェン量を有する土 について，このような試験を行なった結果である。少し例外もある が $(\mathrm{Ap}=20 \%) ，$ 一般にアロフェン量が高いものほど限界初期含水 比は高くなり，これに相当する液性限界も高くなる。液性限界試験 は乱した土の状態量試験であるのでAp 量が高いほど䚌乱による非 自由水分の自由水化の度合いが大きくなるすなわち，Ap 量の高 いものは，低いものより，外部から多くの水を加えられたことに等 しい結果となる。図-6はいろいろなアロフェン量を有する関東口 一ムの空気乾燥による $\mathrm{pF}$ 曲線の変化である。空気乾燥をうけない 土の $\mathrm{pF}$ 曲線はアロフェン量が大きいほど高含水比側にある。ぬた 関東ロームを自然含水比加空気乾燥させていくと $\mathrm{pF}$ 曲線は乾燥 側に移動することが前から知られている4)。この図はこの傾向と一 致するが，アロフェン量が大きいほど移動量が大きい。この移動は ほぼ大から小へのアロフェン量の減少割合に応じて $\mathrm{pF}$ 曲線が乾燥 側へ移動していることがわかる。図-7は，図-6から $\mathrm{pF}=4.2$ (非 自由水分), 及び $\mathrm{pF}=3.0$ (準非自由水分) に相当する含水比を読 みとって綎軸とし, 対応するアロフェン量を横軸にプロットしたも のである。この図から自然含水比の土, 空気乾燥土ともに, その非 自由水分はアロフェン含有量とともに増加し, 両者はほぼ直線関係 にあることがわかる。以上のことからアロフェン粘土鉱物が関東口 一ムの空気乾燥挙動を支配し, 非自由水分の吸着に多大の影響を及 ぼしていることがわかる。図-8は, いろいろなアロフェン量を有 する試料について，そのねり返し時間と液性限界の変化の関係を示 したものである。一般に関東ロームは，ねり返し時間が長くなるほ ど液性限界は低下することが報告されている(1),15)。図-8 は，アロ フェン量が大きいほど，ねり返し時間とともに液性限界が顕著に低 下していることを示している。また，液性限界の低下はあるねり返

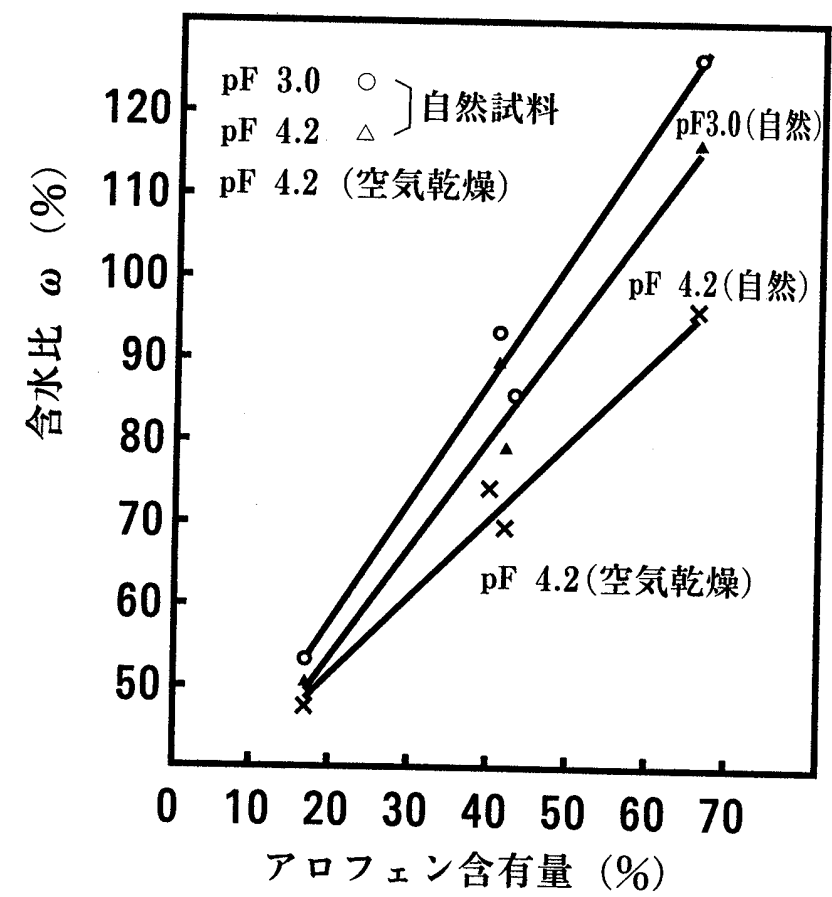

図-7 アロフェン含有量と非自由水の関係

し時間で一定になるが，この時間もアロフェン量が大きいほど長く なることがわかる。この現象は，空気乾燥による液性限界の低下と 同じく，权り返しによるアロフェン粘土鉱物の保持する非自由水分 の非可逆的自由水化によるものである ${ }^{4 y}$ 。低アロフェン量 $(\mathrm{Ap}=20 \%)$ ではこの自由水化現象が顕著でないため, ねり返し による液性限界の低下はほとんど起こらない。図-9は, アロフェ ン含有量と強熱減量の関係である。両者の間には, 次式で表される 直線的比例関係を有している。 


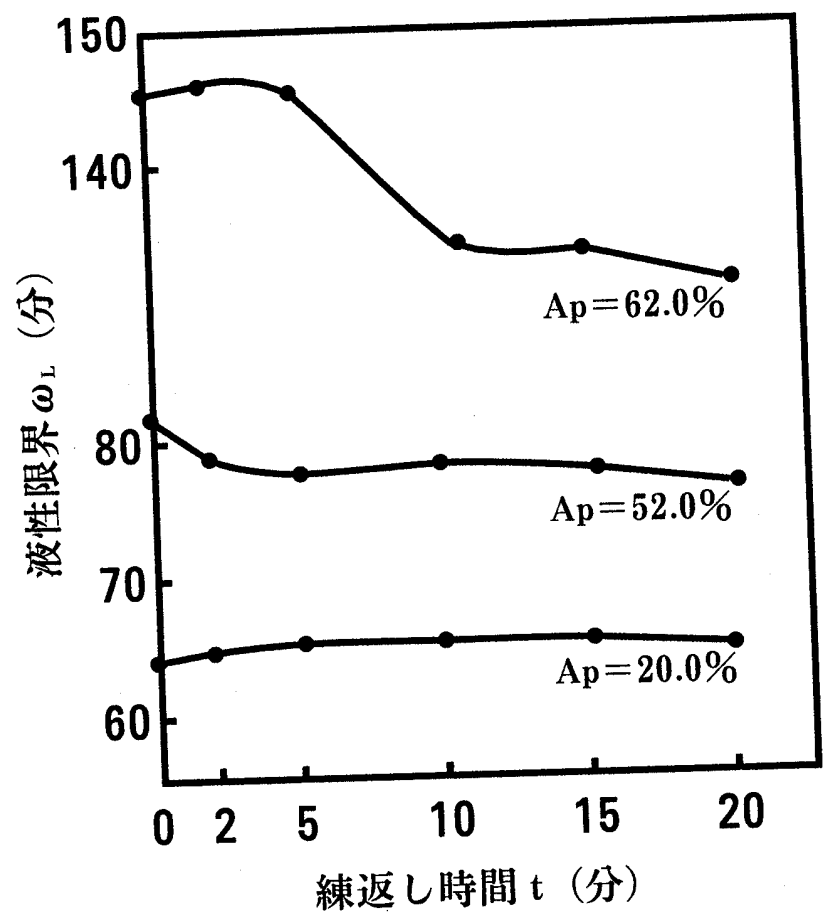

图-8 アロフェン量が叔り返しと夜性限界の関係に及ぼす影響

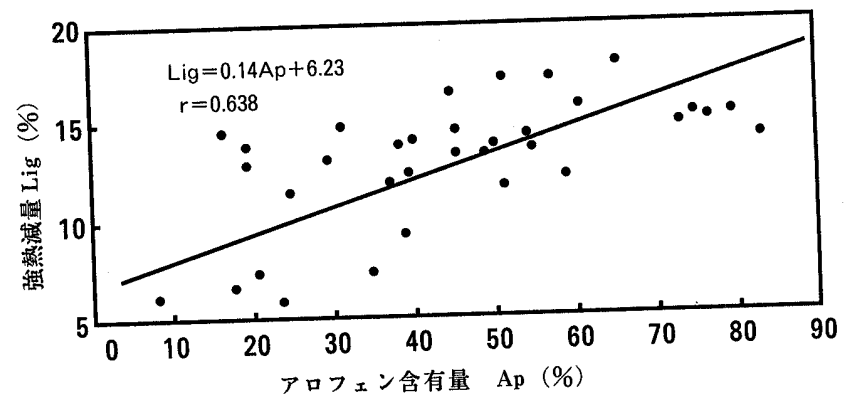

図-9 アロフェン量と強熱減量の関係

$$
\begin{aligned}
& L_{i g}=0.14 A_{p}+6.23 \\
& r=0.638
\end{aligned}
$$

式中の記号は図に示すとおりであり,$r$ は相関係数である。アロ フェン量は地表に近付くほど増加することは, 図-3のX 線回折, 後述の図-23で示されるアロフェン量と乾燥密度の関係から推測で きる。また地表に近いほど植生の影響を受け，有機物が多くなるこ とは, 黒ボク土の存在がこれを示している。これからアロフェン含 有量と強熱减量の間にはある一定の比例関係があることがわかる。 式 (1)はこの関係を示している。な拉, 図-9 加関東口ームの強 熱減量は $20 \%$ 以内にあるが，これは従来から報告されているもの と一致する14)。

3.3 アロフェン量が分散作用に及ぼす影響（図-10～11）

土の粒度分析における懸濁液の分散には，従来から苛性ソーダ， ケイ酸ナトリウム，およびピロリン酸ナトリウムなどの試薬が使用 されてきた。しかし，アロフェン型ロームである関東ロームには酸 性分散が効果的といわれている13),14)。同一種類の土について分散 度を比較するのに沈積粘土分量で表す方法がある11)が，土質工学 的には均等係数で表す方が適当と思われる。図一10は，いろいろな アロフェン量を有する関東ローム試料の懸濁液について, 均等係数

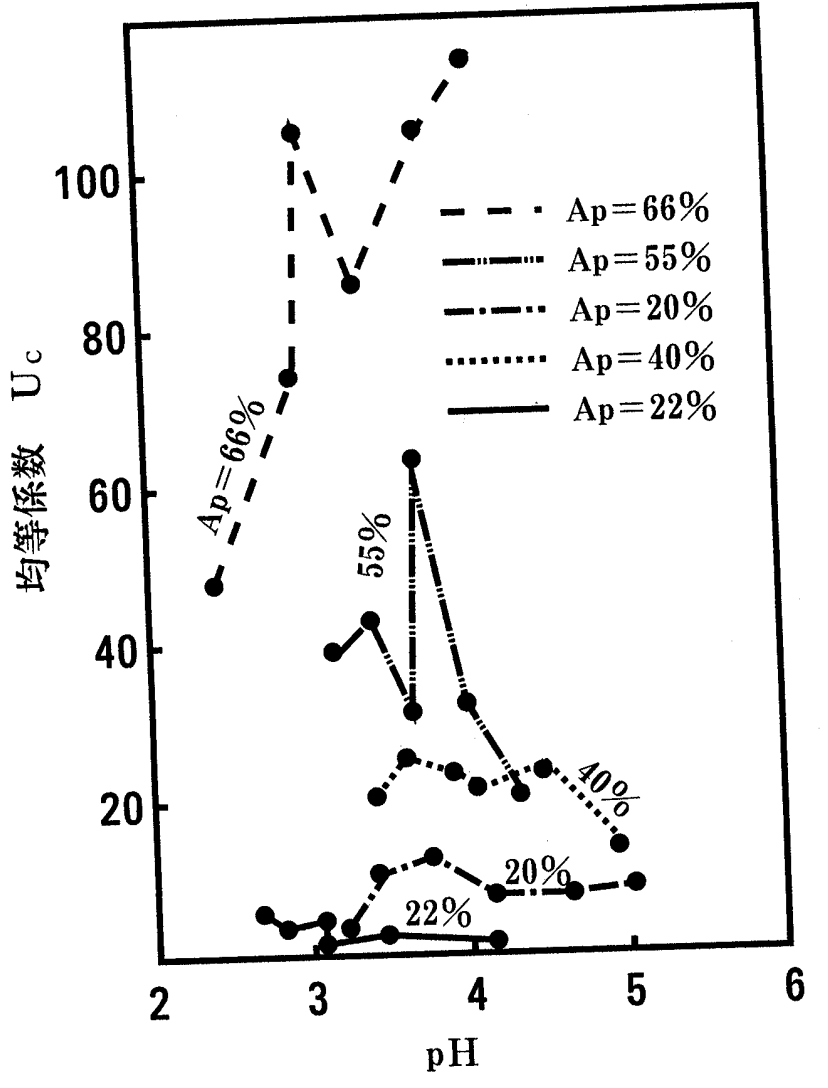

図-10 懸濁液の PH 值と均等保数の関係

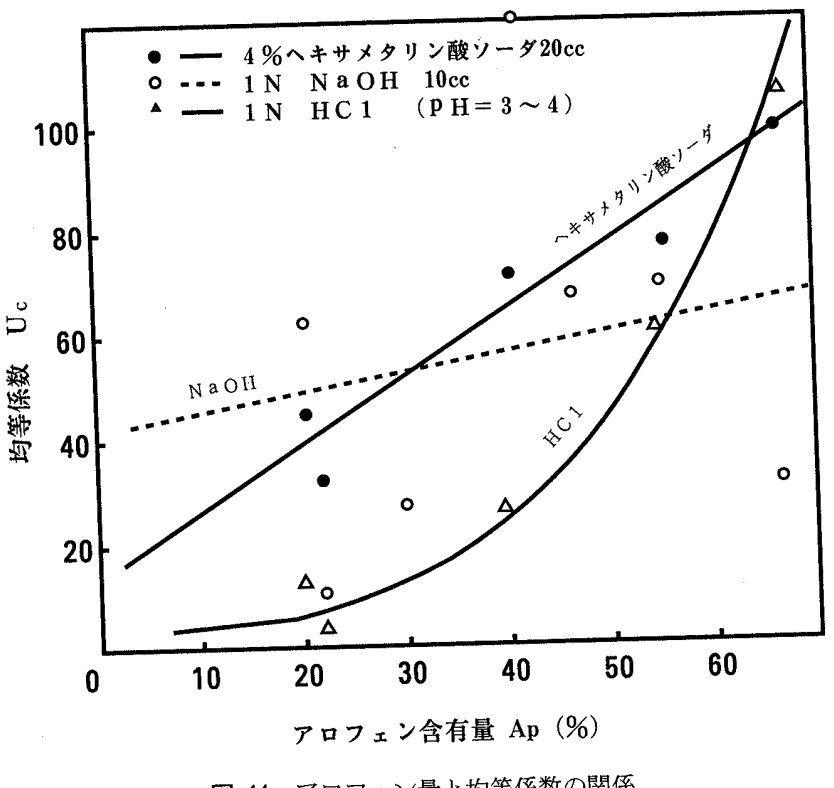

図-11 アロフェン量と均等係数の関係

と 1 規定塩酸を添加した $\mathrm{pH}$ 值の変化についてプロットしたもので ある。この図から，pH值のいかんに関わらず，アロフェン量が増 えると均等係数が大きくなることがわかる。すなわち, アロフェン 量が増えると酸性分散の効果が大きくなる。ぬたアロフェン量のい かんに関わらず，均等係数が最大になる懸濁液の最適 $\mathrm{pH}$ 值は 3 4の間にあることがわかる。 $\mathrm{pH}=3 \sim 4$ になる $1 \mathrm{NHCL}$ の添加量 は，任意のアロフェン量に対して約15２0 ccである。しかし，同 
一量の $1 \mathrm{NHCL}$ 添加に対しては, アロフェン量が増えるほど $\mathrm{pH}$ 值 は小さくなることが確かめられている。図-11は，酸性分散を含む いろいろな分散材の種類がアロフェン量と均等係数の関係に及ぼす 影響を表したものである。苛性ソーダ $(\mathrm{NaOH})$ によるアルカリ分 散ではかなりのバラツキがあり，あまりアロフェン量とは関係ない ようである。しかし，酸性分散ではかなりの相関性が反られる。ア ロフェン量 $60 \%$ まではへキサメタリン酸による分散が効果的であ り，それ以上になると塩酸による分散が卓越してくることがわか る。また塩酸による分散効果はアロフェン量の増加とともに急増す
る。この間, 均等係数はほぼ10から100に増加し, アロフェン量に よって10倍の開きがあることがわかる。すなわち，塩酸による分 散は高アロフェン量を有する関東ロームについてのみ有効である。

3.4 アロフェン量が締固め曲線に及ばす影響（図-12１3）

アロフェン含有量が締固め曲線に影響を及ぼすことは, 早くから 地質学的な層序の違いによる締固め曲線で定性的に指摘されてい る5),15)。すなわち, 締固め曲線の順序は層序と一致し, 新期ローム (Ap 量大) の乾燥密度は古期ローム (Ap 量小)のものより小さく, 立川ロームの乾燥密度が最小であるというのがそれである。また八

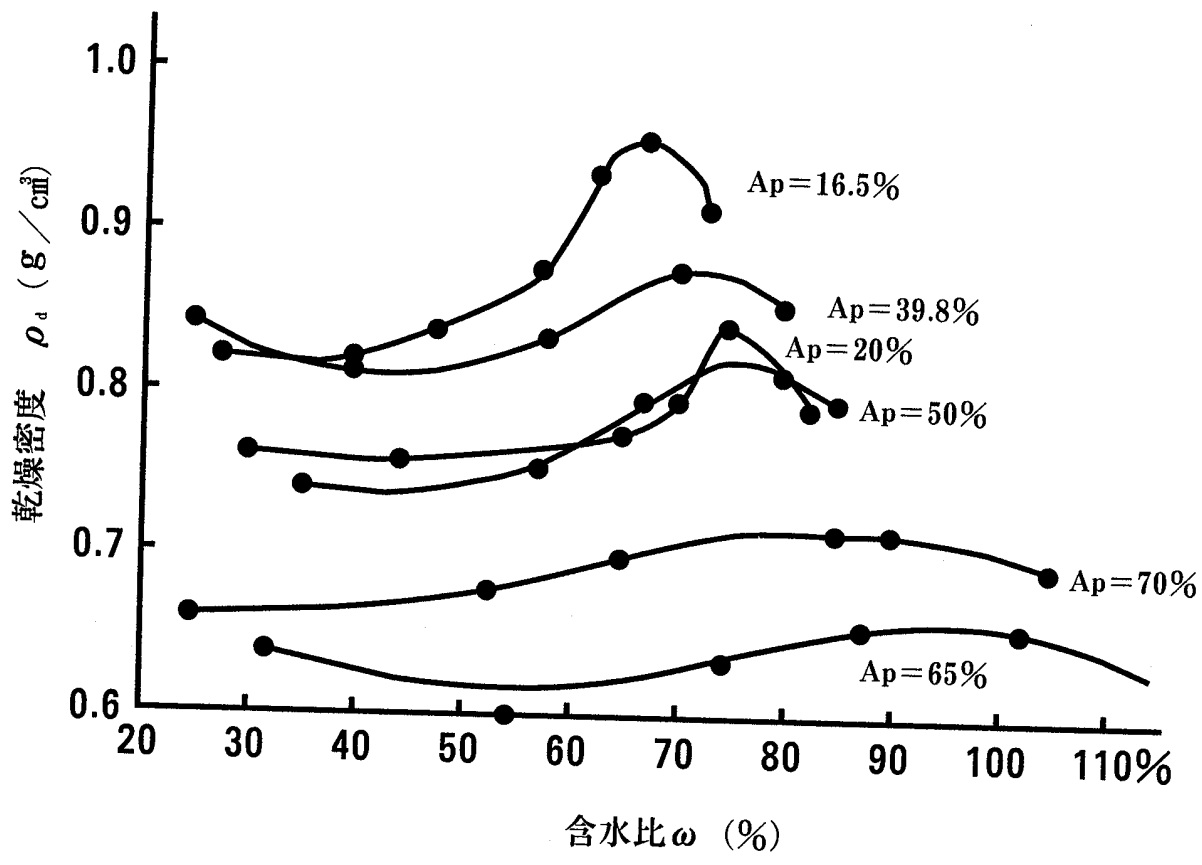

図-12 アロフェン量が締固め曲線に及ぼす影響

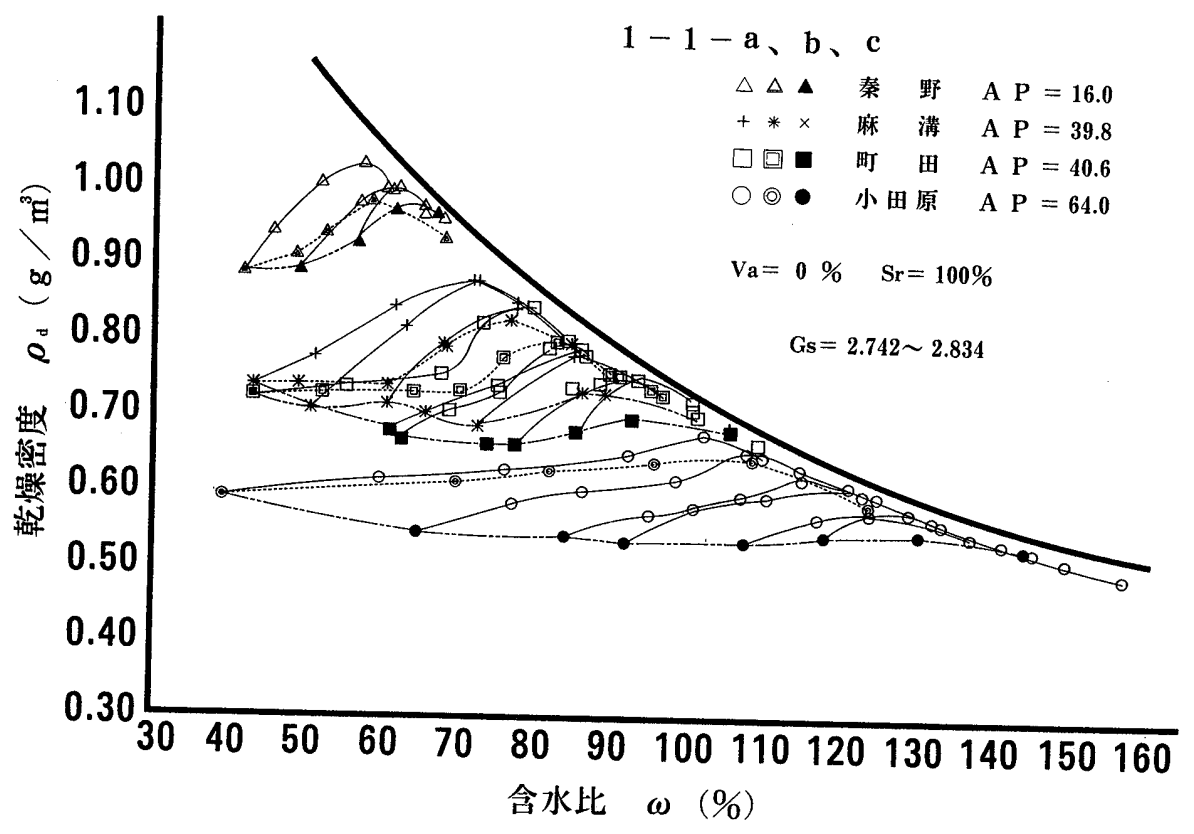

図-13 試料の処理法が締固め曲線に及ぼす影響 
ロイサイトなどを含む粘土化の進んだ古期ロームは, 湿潤法締固め 過程においてもピークが存在し, 乾燥法締固め曲線との間に可逆性 を有しているともいわれている7)。粘上化の進んだ古期ロームのア ロフェン含有量はゼロか微量である。以上のことから関東ロームの アロフェン含有量が, 定性的にも締固め挙動に多大な影響を及ぼす ことが推察できる。よって，いろいろな締固め挙動がアロフェン粘 土鉱物量によってどのような影響を受けるか，それを定量的に示し たのが図-12と図ー13である。

乾燥過程による関東ロームの締固め曲線は, 初期含水比によって 変化する。そこでこの初期含水比をほぼ30\%に固定して，いろい ろなアロフェン量を有する試料について締固めた結果が図一12であ る。アロフェン量が大きくなるにつれて締固め曲線は急な山形曲線 から平坦な曲線になり, 乾燥密度もを机に応じて低下していること がわかる。全試料の最大乾燥密度は, ほほ 0.95 か $50.65 \mathrm{~g} / \mathrm{cm}^{3}$ の 間にあり, 平均は $0.8 \mathrm{~g} / \mathrm{cm}^{3}$ である。農業分野の火山灰土の国際的 分類基準では, 乾燥密度が $0.85 \mathrm{~g} / \mathrm{cm}^{3}$ 以下のものを火山灰土とし ている31)。これはほぼアロフェン量40\%以上のものに相当し, 農 業上の火山灰土はアロフェン型ロームを対象にしていることがわか る。しかし, 工学的にはアロフェン量40\%以下のものも少なくな い。アロフェン量が增えるにつれて乾燥密度が低下する締固め挙動 は，一般土において粘土分が増える場合の傾向と類似している。こ の限りにおいてアロフェンは粘土として作用していることになる。 しかし, アロフェン量は粘土鉱物であるけれども, いつも粘土の挙 動を示すとは限らない。アロフェン量は関東ロームの粘土分と比例 しないことがその一例である29)。図-13は初期含水比を約 $40 \%$ に固 定し, 大中小のアロフェン量を有する試料について, 試料の処理法 の違いによる締固め曲線への影響を調べたものである。ここで試料 処理法の違いとは, 乾燥繰り返し法 (a 法), 乾燥非繰り返し法 (b 法), 湿潤法 (c 法), ならびに湿潤過程での初期含水比の違い による締固め挙動をいう。まず乾燥繰り返し法（a 法）と湿潤法 (c 法) の比較では, アロフェン量が大きくなるほど両者の非可逆 性が大きく, 逆にアロフェン量が小になるほど両曲線の相似性がよ くなることがわかる。この極限は，アロフェン量ゼロになった一般 土で, この場合は両者が完全に一致し，可逆性を有している これはまたハロイサイト化した下末石ローム層以下の関東ロームの 挙動でもある。また試料の繰り返し使用 (a 法) と非繰り返し使用 ( $\mathrm{b}$ 法) の比較では, 前者による乾燥密度は, 後者によるものより も大きくなる傾向にある。しかし，アロフェン量の影響については あまり明膫な差異は認められない。一方，湿潤過程でのおのおのの 初期含水比から締め始める挙動では, 締固め曲線の乾燥側々湿潤側 で明瞭な差異を生じている。すなわち，アロフェン量のいかんに関 わらず，乾燥側では初期含水比が小さい汪ど曲線は上位に位置し， 湿潤側ではほぼゼロ空気間腺率曲線に沿って移動していることがわ かる。この場合でも, ほぼアロフェン量 $40 \%$ で乾燥密度が $0.85 \mathrm{~g} /$ $\mathrm{cm}^{3}$ である。

3.5 アロフェン量がオーバーコンパクションに及ばす影響（図一 $14 \sim 16)$

関東ロームは一般土に比べてオーバーコンパクションになりやす いことは，その特異的な性質の一つとしてつとに知られている16)。 図一14はオーバーコンパクション特性を調べるために用いた試料の 標準締固め曲線（3 層 $\times 25$ 回 $\times 40$ \#ハーバード型）である。図一12な どと同様に，アロフェン量が大きくなるとともに乾燥密度が低下す る正常な挙動を示している。この標準締固めのほかに, オーバーコ ンパクションをも含めた，いろいろの異なるエネルギーで締固めた
曲線のアロフェン量と最大乾燥密度の関係を示したのが図一15であ る。これからアロフェン量とは無関係に締固めエネルギーが大きい ほど最大乾燥密度も大きくなり, 過度のエネルギーによる最大乾燥 密度の減少はみられない。つまり, 最大乾燥密度に関しては, 字義 ど抢りのオーバーコンパクションは存在しない。図ー16はアロフェ ン量のオーバーコンパクションに及ぼす影響を示したものである。 $\mathrm{Ap}=20 \%$ 付近でやや異常挙動を示すが，一般にアロフェン量のい かんに関わらず，エネルギーの増加とともに $q_{u}$ は増加し，55回で 25回とほとんど同じになるまで $q_{u}$ は低下する。すなわち，オーバ ーコンパクションは, アロフェン量と無関係に55回で起こる。こ の理由は次のように考えられる。図-15にみられるように締固め回 数 25 回々 40 回の間の乾燥密度の増加は小さく, 間隙の減少による

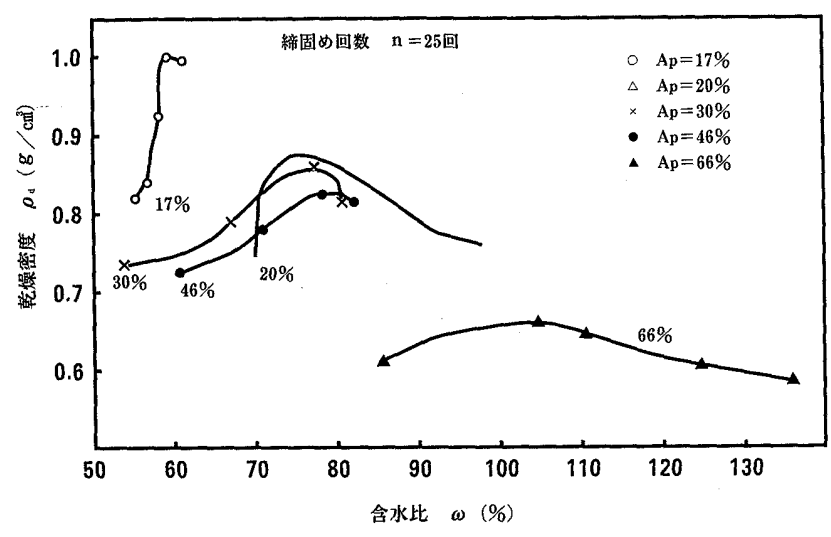

図-14 オーバコンパクション試験試料の締固め曲線

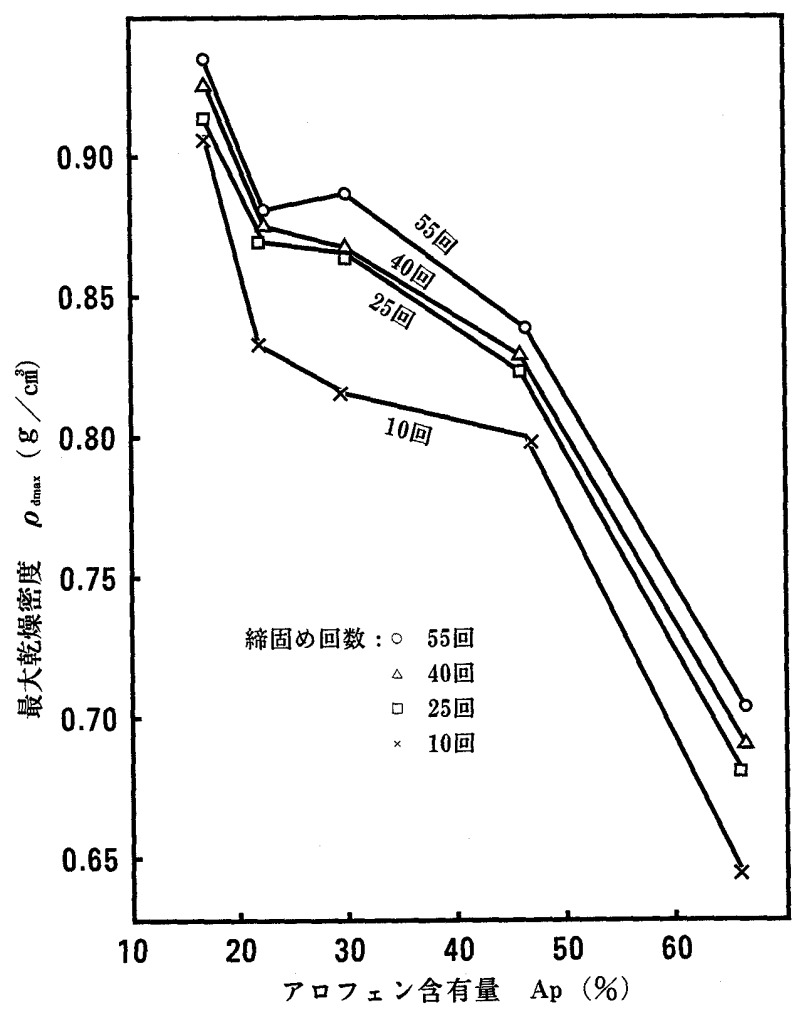

図-15 いろいろなエネルギーで締固めた試料のアロフェン量と最大乾 燥密度の関係 


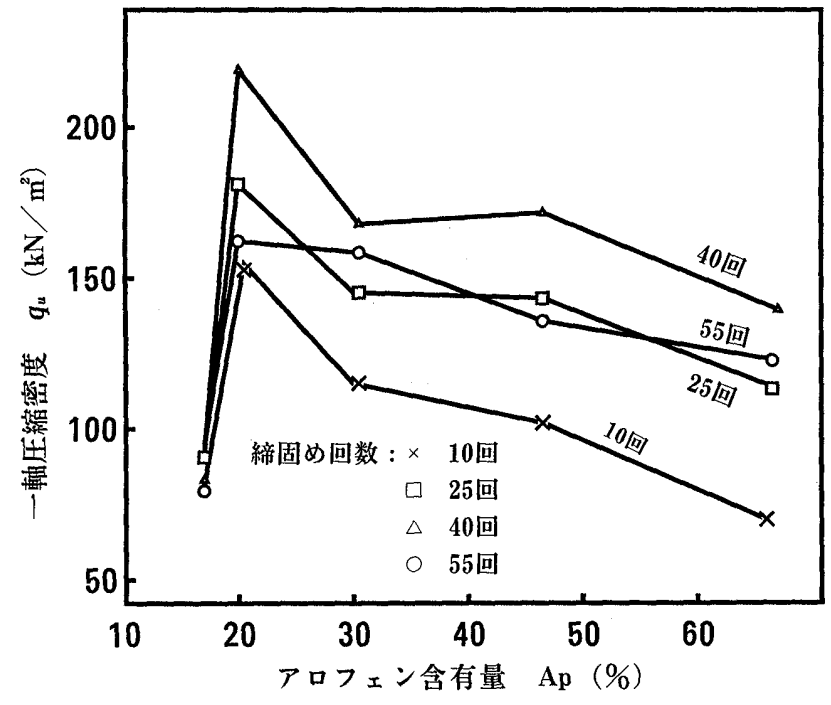

図-16 アロフェン量のオーバコンパクションに及ぼす影響

密度の増加は限界に達したことを示している。しかし，回数を55 回に増やすと乾燥密度は急増している。この間の乾燥密度の増加 は, 締固め攪乱による非自由水の自由水化, 団粒の破壊などにより 高密度化されたものと考えられる。この自由水の増加は, 同時に図 -16で示される55回締固め供試体の $q_{u}$ の減少となって現われてい

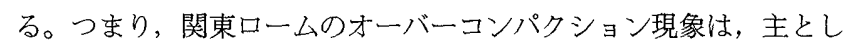
てアロフェン粘土鉱物の非自由水の自由水化による含水比の增加々 それに伴う $q_{u}$ の減少によるものであることがわかる。しかし，ア ロフェン量の差によるオーバーコンパクションの程度に及ぼす影響 はあまりみられない。すなわち, アロフェン量はオーバーコンパク ションに無関係である。

3.6 アロフェン量が強度回復（シキソトロピー現象）に及ぼす 影響（図-17〜19）

関東ロームは, 前述のオーバーコンパクションのほかに顕著な強

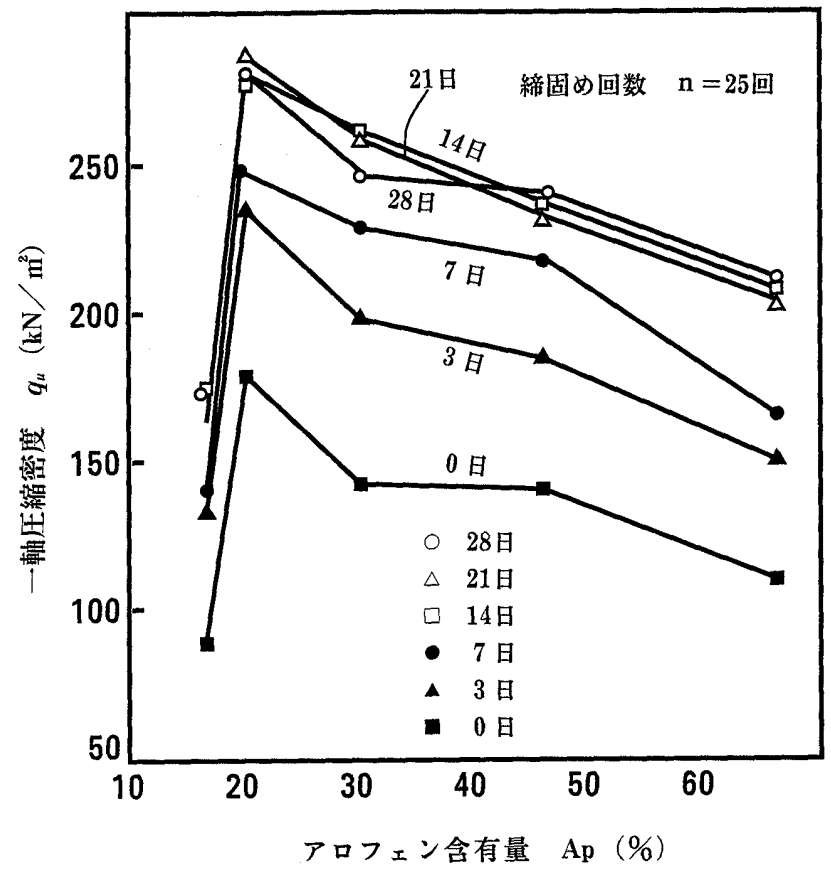

图-17 アロフェン量が強度回復に及ぼす影響
度回復現象を有することは，早くから指摘されている17)。図一17は アロフェン量が，この強度回復現象に及ぼす影響を示したものであ る。この図からアロフェン量のいかんに関わらず，qu養生とと もに増加し，14日でほぼ一定になる。強度回復が14日で終了する ことは, 過去の研究とも一致している17)。この強度回復現象は, 締固めに抢污こ敉返しが非自由水を自由水化し, さらに静置養生 することによって再び非自由水にもどる硬化現象であると考えられ ている。この非自由水には不可逆な構造的非自由水之可逆的な溶媒 和非自由水があり, 強度回復に扔いて作用するのは後者の可逆的非 自由水であるとされている4)。図-17は正常締固め供試体 $(n=25$ 回) についてのものであるのに対して, オーバーコンパクションになる 締め回数55回の供試体の強度回復を示したのが図-18である。この 図からオーバーコンパクションになっても，アロフェン量と無関係 に14日で強度回復が終了していることがわかる。すなわち, 強度 回復現象はオーバーコンパクションに無関係である。図一19はオー バーコンパクションを含むいろいろな締固めエネルギーで締固めた 供試体について, アロフェン量と強度回復率の関係を示したもので

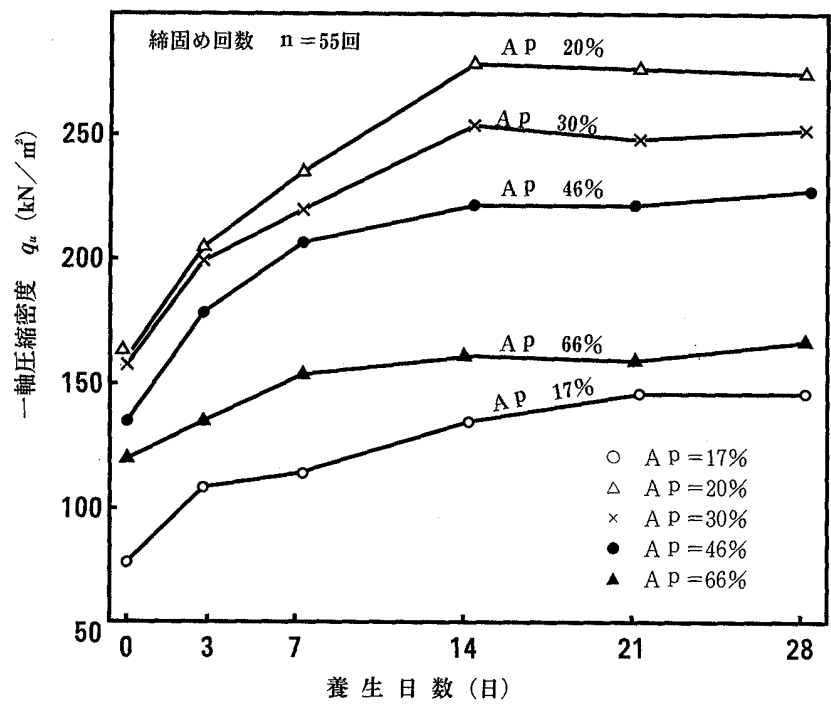

図-18オーバコンパクション供試体の強度回復

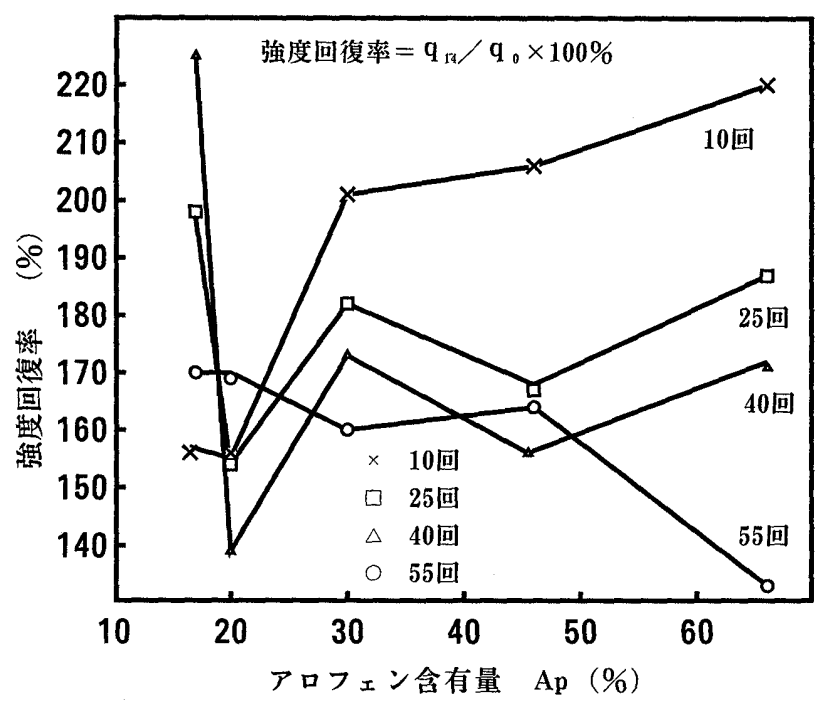

図-19 アロフェン量が強度回復率に及ぼす影樴 
ある。ここで

$$
\text { 強度回復率 }=\frac{\text { 養生 } 14 \text { 日の強度 }\left(q_{14}\right)}{\text { 養生ゼロ日の強度 }\left(q_{0}\right)} \times 100 \%
$$

で表す。

$q_{u}$ 供試体作成時の不備によるものと思われる少しのバラツキは おるが $(\mathrm{Ap}=20 \%)$ ，この図から正常締固め状態では，アロフェン 量が増えると強度回復率は増加し，オーバーコンパクション状態で は $(n=55$ 回)，逆に減少することがわかる。従来から，新期ロー ム（Ap 量大）ほどその強度回復は大きいといわれている肪，こ の図はそれを定量的に裏付けるものである。 $n=25$ 回の標準締固め では, 原強度の約1.5 2 倍の強度回復があり, アロフェン量の違 いによる強度回復率の差は $30 \%$ になる。オーバーコンパクション での強度減少率の差も同じく30\%である。以上のようにアロフェ ン含有量はオーバーコンパクションと強度回復時間とは無関係であ るが，強度回復率とは密接な関係を有することが結論付汀られる。

\section{7 アロフェン量が鋭敏比に及ぼす影響（図-20～21）}

乱さない状態の関東ロームは，一般に $10 \mathrm{~m}$ 近くまで斜面の自立 可能であり，支持地盤としては 3〜4 階建物の荷重に十分耐えうる ことが知られている2)。しかし基礎地盤の攪乱による支持力の低下 （杭打ちなど，盛土のねり返しなどによるトラフイカビリテイ確保 の困難性を引き起こすことなどは，関東ロームの鋭敏比の重要性を 示すものである。一般に関東ロームの鋭敏比は高く，10以上とい われている9),32)。図-20は，いろいろなアロフェン量を有する関東 ロームの乱さない土と乱した土の一軸圧縮強度 $\left(q_{u}\right)$ の変化を示し たものである。乱さない土の $q_{u}$ は78.4 $383 \mathrm{kN} / \mathrm{m}^{2}(0.8 \sim 3.8 \mathrm{kgf} /$ $\left.\mathrm{cm}^{2}\right)$ と幅広く，注目すべきは，アロフェン含有量の増加とともに 増加していることである。 $q_{u}$ に関する限り，アロフェン粘土鉱物 は粘土の挙動ではないと考えることができる。この現象はボーリン グデータによっても報告されている29)。関東ロームの乱さない土 の強度は，その多孔構造，毛管力，抢よび啇度の粘着力によるもの とされている22,4),31)。このうちでもアロフェン粘土鉱物は粗の多孔 構造と粘着力に大きく寄与しているものと思われる。多孔構造は本 来砂質土の特性である。アロフェンロームが完全に粘土挙動を示さ ない理由がここにもある。図-21は図-20から計算された鋭敏比とア ロフェン量の関係である。両者はほほ比例関係にある。鋭敏比は 6 以下であり，従来からいわれているほど高いものではない。表一 1 に示すように関東口一ムは地質学的には地表加ら地下に向加て 新期ロームから古期口ームへと変化している。一般に地表の新期口 一ムはアロフェン量が多く，古期ロームはほとんどない代わりによ く粘土化されている。一般に高い鋭敏比を示すものは深層にあるこ れらの完全に粘土化された古期ロームである。これらの古期ローム はアロフェン量が少なく，代わりに粘土化の産物である加水八ロイ サイト，ハロイサイトなどを含んでいる。加水ハロイサイトのみを 多く含有する灰土の鋭敏比が高いことが報告されている32)。これ から関東ロームの高い鋭敏比を支配しているものはアロフェン粘土 鉱物でなく，ハロイサイトなどの深層粘土鉱物であるといえる。図 -21ではアロフェン量30～50\%の間で高い鋭敏比を示すバラツキが あるが，アロフェン量が低いところでは，加水ハロイサイが多くな るので，この影響によるものと思われる。

3.8 アロフェン含有量が透水性に及ばす影響（図-22２3）

関東ロームの透水性に関して，現在まで知られている一般的知見 は，乱さない土の透水係数は乱した土より大きく，約 $10^{-2} \sim 10^{-3}$ $\mathrm{cm} / \mathrm{sec}$ のオーダーである。これは乱さない土が粗い間陌に富むこ とによるものであるが，乱されるとこの団粒構造が破壊されるため である2)。この構造の重要性のため関東ロームの透水性は，単に間
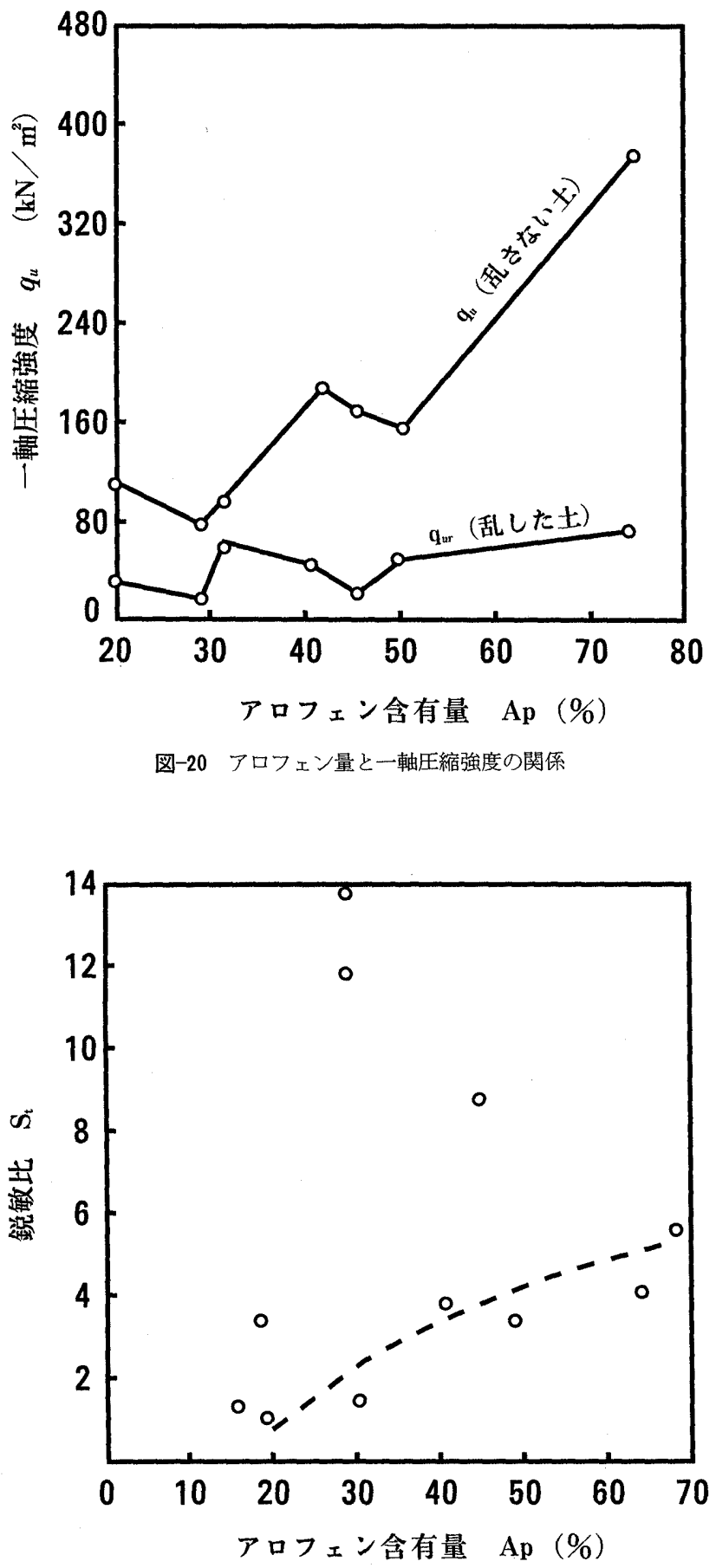

図-21 アロフェン量と鋭敏比の関係

隙の大きさに依存しない。またその層に垂直方向の透水性注水平方 向のものよりも数倍も大きい透水異方性を有している2)。これは垂 直方向のき裂が水平方向のものよりも発達しているためである。し かし, これらの通説もアロフェン量と乾燥密度を規定しない限り, 一定しないものがあると考える。一方，関東ローム層の建設現場で は，トレンチ内などの雨水の排水性が場所により大きな差異がある ことが経験的に知られている。この原因は地盤のアロフェン含有量 の差によるものと考え，著者は一連の透水試験を行なってきた。ア ロフェン量と透水性の関係について考えられる問題には次の 4 点 がある。

（1）乱さない土のアロフェン量と透水係数の関係 
（2）アロフェン量のいかんを問わず，すべての試料を同一乾 燥密度に締固めた時の透水性の比較（乱した土のアロフェン量と透 水係数の関係)

（3）アロフェン量別の締固め曲線に応じた最適含水比で締固 めた場合のアロフェン量と透水係数の関係

（4）一定のアロフェン量を有する試料について，乱さない土 の乾燥密度と同じくした締固め供試体の透水係数の比較（乱した土 と乱さない土の比較）

このうち, 第 (1)点について, 乱さない土のアロフェン量と透 水係数の関係を示したのが図-22中の点線である。ややバラツキは あるがアロフェン量の増加につれて乱さない土の透水係数も大きく

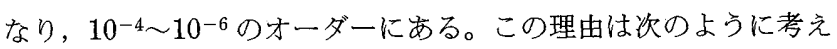
られる。一般にアロフェン量は地下から地表に向かって増加してい る, また乾燥密度も自重による上載荷重の減少により, 地下から地 表に向かって減少しているので透水性仿同方向に増加する。ゆえに 図-23に示すようにアロフェン含有量が増えると乾燥密度は減少す る傾向にある。すなわち, アロフェン量が増加するにつれて透水係 数も増加することになる。また図-23で知れるようにアロフェン量 40〜50\%から乾燥密度が急激に低下するので図-22では乱さない土 の透水係数もこの付近で急に增加することがわかる。アロフェン量
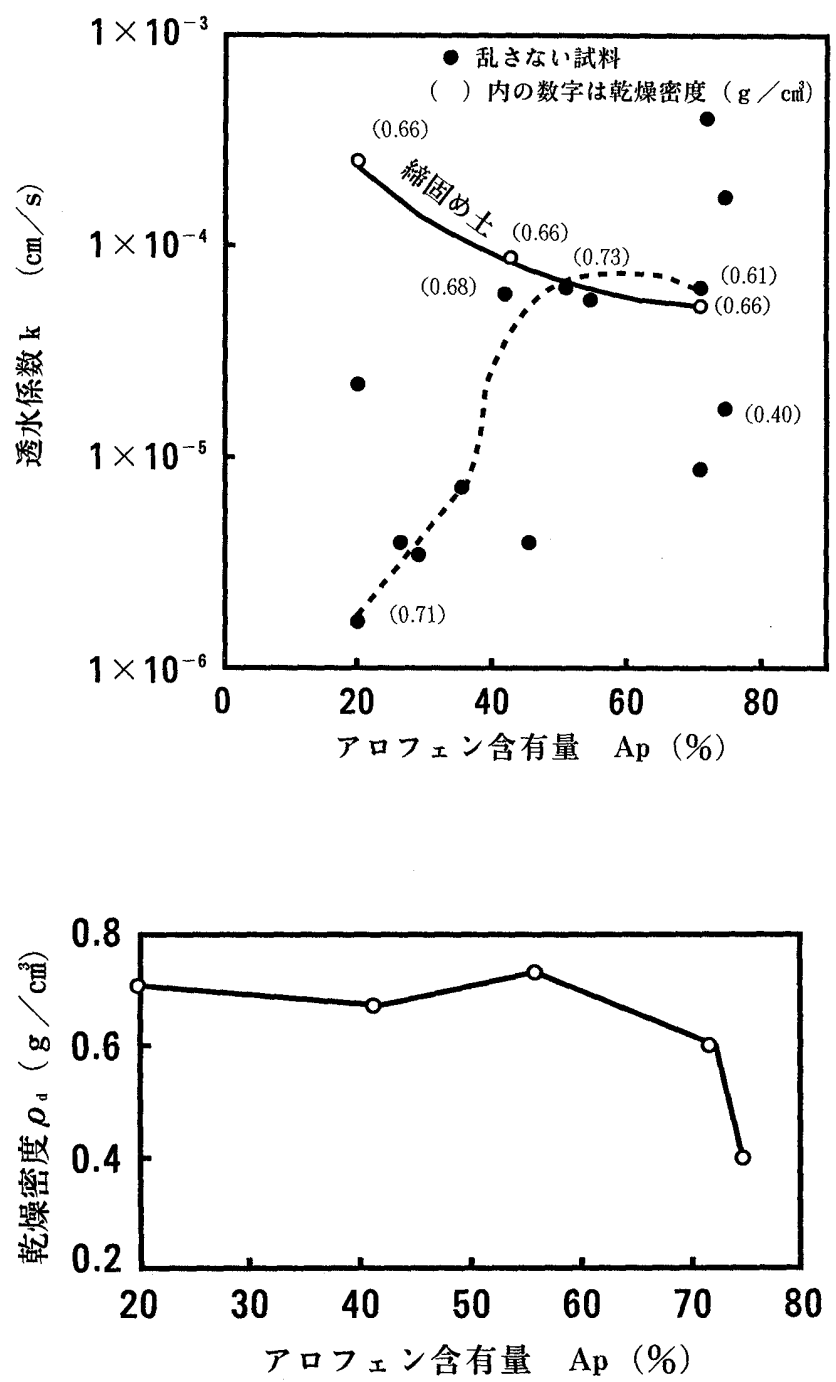

図-23乱さない試料のアロフェン量と乾燥密度の関係
が40～ $50 \%$ 付近で透水性が急変することは，著者によってすでに 報告されてきた 23),24)。第 (2) 点では,すべての試料を同一乾燥密 度に $\left(\rho_{d}=0.66\right)$ 締固めた時の透水性を比較する問題であるが，こ れは図-22中の実線で示されている。透水係数はアロフェン量の増 加とともに減少している。締固めにより，乱さない土特有の団粒構 造が破壊され，アロフェン粘土は粘土本来の挙動に転ずるためと考 えられる。一般に粘土分が多いほど締固めの透水性が減少するの で, 乱されたアロフェン粘土はこれに類似した挙動となる。（3） の問題ではアロフェン量が増えると締固め曲線は平坦になり, 乾燥 密度は低下するので，それに対応した最適含水此で締固めた供試体 の透水係数は当然増加する。すなわち，この場合は（1）と同様に アロフェン量の増加とともに透水係数は增加することは著者によっ てすでに報告されている23),24)。また(4)では，一定のアロフェン 量を有する試料に対して，同一密度を有する乱した土と乱さない土 の透水性の比較であるが, 空気乾燥しない限り乱した土には粘土の 挙動が現われるので, 通説のように乱さない土の透水係数は乱した 土より大きくなる。しかし, 空気乾燥土では, 空気乾燥の程度によ りこの限りではない。一般に空気乾燥すると透水係数は増加する傾 向にある。

\section{4. 結論}

以上の研究結果から次のような結論が得られる。

（1）アロフェン量が減少するとともに順次加水ハロイサイト， ハロイサイトが増加する。加水ハロイサイトはアロフェン量 $50 \%$ 以下になって始めて混在する。

（2）アロフェン量の増加とともに自然含水比は増加し，自由 水の空気乾燥は14日で完了する。

（3）アロフェン量が大きくなるにつれて，空気乾燥による限 界初期含水比および $\mathrm{pF}$ 曲線の乾燥側移動量はともに大きくなり, またねり返しによる液性限界の減少も大きくなる。

（4）アロフェン量と強熱減量, または $\mathrm{pF}=4.2$ の非自由水分と は，おのおの正の直線関係にある。

（5）高アロフェン型ローム $(\mathrm{Ap}>60 \%)$ は酸性分散の方が有 効である。有效な $\mathrm{pH}$ 值は $3 \sim 4$ の間にある。

（6）アロフェン量が増えると締固め曲線は平坦になり，乾燥 密度は低下し, 乾燥, 湿潤法間の締固め曲線の非可逆性が大にな る。

（7）オーバーコンパクションは締固め回数55回で起こり，ア ロフェン量に無関係である。しかし, 締固め供試体の強度はアロフ エン量の增加とともに減少する。

（8）強度回復現象は14日で終了し，この時間はアロフェン量 やオーバーコンパクションと無関係である。

（9）アロフェン量が増加するにつれて強度回復率は増加し， オーバーコンパクション供試体では逆にその強度回復率は減少す る。

（10）乱さない土の $q_{u}$ と鋭敏比はアロフェン量とともに増加す るが，非アロフェン粘土の鋭敏比ほど高くない。

（11）乱さない土の透水係数はアロフェン量とともに増加し， 特に $40 \sim 50 \%$ 以上で透水性の増加が著しい。同じ乾燥密度に締固 めたものは，逆にアロフェン量の増加とともに減少する。

本研究は, この $4 \sim 5$ 年来, 土質工学会研究発表会などで発表し たものをも含めて，とりをとめたものである。最後に本論文の作成 にあたり，関東ローム試料の採取に多大の御協力をいたたいた清水 建設横浜支店土木部長坂泱一郎氏，ならびに鹿島建設土木本部次長 
村田曄昭氏に感謝の意を表して止なない。をた, 実験の一部を担当 した列届宋研究室の大学院生および学部卒研生諸君の努力に感謝す る。

\section{参 考 文 献}

1）関東ローム研究グループ (1965) :「関東ローム」, 築地書館.

2）高速道路調査会（1973）：「関東ロームの土工一その土質と設計施工」, 共立出版.

3）北川靖夫（1975）：アロフェンの脱水, 微細形態抢よび化学組成, 「農 技研報告」, B26, pp. 95 131.

4）山崎不二夫 ·須藤清次 (1965)：土の工学的挙動一関東ロームを中心と して,「農土論集」, No. 14, pp. 1 10.

5）三島史郎・里木荘平 (1968) : 関東口ームの地質工学的研究, 「第 3 回 土質工学研究発表会」, pp. 17 22

6）多田 敦・山崎不二夫等 (1965) : 関東ロームにおける新期ロームと古 期口ームの物理的性質の比較, 「農土論集」, No. 14, pp. 67 70.

7）土壤物理研究会編（1979）：特殊土の物理的性質（「土の物理学」, 第 12章）森北出版, pp. 311 330.

8）土質工学会（1974）：火山灰質粘性土（「日本の特殊土」，第 2 章）, pp. $22 \sim 83$.

9）吉国 洋等（1984）：火山灰質粘性土（「土の力学II」），技報堂出版， pp. 3 33.

10）相馬尅之（1978）：初期含水比が土の液性塑性限界に及洔す影響，「土 壤の物理性」, No. 38, pp. 16〜22.

11）飯竹重夫 (1978): 関東ロームのコンシステンシー特性について,「土 木学会論文報告集」, No. 277, pp. 85 93.

12）山崎不二夫・竹中 肇（1965）：風㲦がアッタベルク限界に及ぼす影 響, 「農士論集」, No. 14, pp. $46 \sim 48$.

13）多田 敦 (1965)：火山灰土の粒度分析の問題点, 「土質工学会第10回 シンポジウム」, pp. 23〜26.

14）土質工学会 (1990）:「土質試験の方法々解説」(第 2 章関東ローム), pp. $496 \sim 508$

15）安富六郎・竹中 肇（1970：関東ロームの対り返しによる工学性の変 化について,「関東ロームに関するシンポジウム」, pp. 17〜20.

16）久野悟郎（1964）：「土の締固め」，技報堂，pp. 85〜100.

17）島 博保 (1970): 関東ロームの強度特性について,「関東ロームに関 するシンポシウム」, pp. 21〜28.
18）持永龍一郎，里木康夫 (1970)：灰土(阿蘇火山灰土)の土性について, 「関東ロームに関するシンポジウム」, pp. 69〜74.

19）多田 敦（1965）: 関東ロームの締固めと透水俰数について,「農土論 集」, No. 14, pp. $30 \sim 45$.

20）有泉 昌・牧 隆正 (1964)：アロフェン質粘土の消石灰一石膏による 化学的安定処理方法に関する研究 (6)，「土木研究所報告」，No. 122, pp. $35 \sim 60$.

21）日本石灰協会（1970）:「石灰による土質安定処理工法」, 山海堂, pp. $1 \sim 35$.

22) E. K. So and F. Okada (1988): "The physicochemical properties of residual strength of volcanic soils in Japan," Proc. Intern. Conf. Eng. Problems of Regional Soils, Beijin China, pp. 701-706.

23）宋 永焜 (1991) : 関東ロームのアロフェン量と土質工学的性質の関 係,「粘土釷物試験結果の活用シソポジム発表論文集」, 土質工学会, pp. $61 \sim 66$.

24）宋 永焜 (1991)：火山灰粘性土のアロフェン量が工学的性質に及ぼす 影響, 「材料」, Vol. 40 , No. 459, pp. 9 15.

25) Wesley, C. D. (1973): "Some basic engineering properties of halloysite and Allophane Clays in Java Indonesia," Géotechnique Vol. 23, No. 4, pp. 471-494.

26) Wesley, C. D. (1977): "Shear strength properties of Halloysite and Allophane Clay in Java Indonesia," Géotechnique Vol. 27, No. 2, pp. 125 136.

27）宋 永显（1993）: 関東ロームのアロフェン含有量が生石灰安定処理土 の含水比に及ぼす影響，「第28回土質工学研究発表会」, pp. 2593〜 2594.

28）宋 永焜等：関東ロームのアロフェン含有量が生石灰一石膏安定処理 土に及ほす影響，「土質工学会論文報告集」，投稿中.

29）窪田す反江・金井太一・飯竹重夫（1993）：南関東に分布する新期口一 ムのアロフェン含有量, 「土木学会第20回関東支部技術研究発表会概要 集」, pp. $270 \sim 271$.

30）北川靖夫（1977）：土壤中のアロフェンおよび非晶質無機成分の定量に 関する研究，「農技研報告」，No. 29, pp. 1 48.

31）前田 隆・相馬赾之（1983）：火山灰土の物理性と工学性（日本土壤肥 料学会編, 4, 「火山灭土」, 博友社), pp. 99 139.

32）喜田大三・中田礼喜 $(1970)$ : 火山灰土の $\mathrm{pF}$ 水分に関する二, 三の知 見，「関東ローム関するシンポジウム」,pp. 39〜44. 